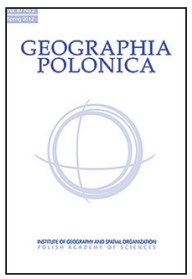

\title{
THE VISION OF EUROPE AND THE WORLD AS SEEN BY LARGE POWERS: THE CASE OF THE BRIC COUNTRIES
}

\author{
Vladimir Kolossov \\ Russian Academy of Sciences \\ Institute of Geography \\ Staromonetny pereulok 29, 119017 Moscow: Russia \\ email address: vladimirkolossov@rambler.ru
}

\begin{abstract}
The paper is based on results within the framework of the project "The vision of Europe in the world" as supported by the 7th European Framework Programme; and in particular on a survey carried out on undergraduate students from 18 countries. The work concerns specific features of the world geopolitical vision characterising respondents from large countries (Brazil, Russia, India and China - the BRIC countries), as set against the place of these countries in the 'global space of flows' after Manuel Castells.
\end{abstract}

\section{Key words}

world geopolitical vision - BRIC countries $・$ geographical images perception

\section{Territorial identity, 'low geopolitics' and world geopolitical vision}

It is known that the role, perception and use of space by individual people and by groups in society change constantly in relation to social practice (Harvey 1989). The latter includes, in particular, political discourse, whose objective is the modification or strengthening of certain social representations, with an important role being played in the shaping of human territoriality and the political map. In line with the definition from R. Sack (Sack 1986), the delimitation and control of territory is used by an individual or a social group to exert influence on other people, their relations and social processes (Sack 1986). However, it transpires that every social and regional group has its own image of territory, and while these sometimes match, they often contradict each other sharply.
The theory of the social construction of space has contributed to a deep transformation of methodological approaches in geopolitics, and to the emergence of the so-called critical geopolitics (Ó'Tuathail 1996, 2003, 2006; Dalby \& Ó'Tuathail 1998; Mamadouh \& Dijkink 2006). Through it, the gap between the studies of domestic and foreign policy proper to positivist approaches, between political geography and geopolitics, is overcome or at least narrowed. In traditional, or neoclassical geopolitics, the state is studied as a single entity, as a 'black box' reacting in a certain way to external challenges. Specifically, 'national interests' in the understanding of the elite, were automatically ascribed to all the country, to its entire population.

In contrast, critical approaches interpret geopolitics as a discourse dominated by statesmen 
and politicians interested in the creation of a specific simplified world geopolitical vision capable of serving their needs.

One of the key concepts of critical geopolitics is the 'world geopolitical vision'. It can be defined as a normative mental political map of the world or of a region in combination with representations concerning political actors, elements of political space, national security, and the advantages and shortcomings of different strategies in foreign policy (Dijkink 1996, 1998). The world geopolitical vision also includes representations relating to the territory and boundaries of the state and/or ethnic group, the best political regimes and models of the state, and external and internal forces contributing to or hindering their realization.

The world geopolitical vision is shaped under the impact of family traditions, education, personal experience, advertising, literature and art, cinema and especially mass media creating and diffusing a set of myths and stereotyped representations about national history and territory (Sharp 2000; ÓTuathail 2006; Dodds 2008). These representations are diffused in the process of political discourse summarizing some information on international affairs or the political situation attached to a territory. The world geopolitical vision is rooted in geopolitical traditions - historically determined national political-philosophical schools developing a certain normative and formalized set of views on national identity, interests and political priorities (ÓTuathail 2006).

The key idea of critical geopolitics is the need for the interaction between 'high' and 'low' geopolitics to be studied. While the former is shaped by political leaders, academics, journalists and other professionals dealing with international relations, the latter comprises a set of social representations about the place of a country in the world, the principles and the orientation of its foreign policy, potential allies and external threats to its security, symbols and images. In a modern democratic society, 'high' and 'low' geopolitics are inseparable: though they may develop autonomously, they complement and feed each other. 'Low' geopolitics is based on national geopolitical culture, is an intrinsic element of national identity, and may serve as an important instrument in state building. It is also 'low' geopolitics that determines the support a state's foreign policy receives from public opinion (Archer et al. 1997; Brewer et al. 2004).
Surveys, focus groups and interviews with experts form a key set of methods where the study of 'low' geopolitics is concerned. The objective of a recent series of interdisciplinary studies based on representative surveys conducted in many countries, in particular Russia, was to reveal the relationships between the sex, age, social status, income and political values of citizens on the one hand, and on the other their representations of the world, images of foreign countries and opinions regarding important political problems (Kolossov 2001, 2003a, 2003b; O'Loughlin 2001; O'Loughlin \& Kolossov 2002; O'Loughlin et al. 2005, O'Loughlin \& Talbot 2005, etc.). The authors of the studies focused on the stability and origins of popular representations, on the role of mass media in the creation of these, and their dynamics, and on relationships with political discourse. The results of such surveys are now used more and more regularly in the compiling of mental maps, including cartograms (Le Monde Diplomatique 2009, etc.).

A special question concerns the way in which the world geopolitical vision varies from one region, and one type of settlement, to another. It is logical to suppose that, in large countries in particular, the representations in the minds of those living in capital cities differ from those maintained by the inhabitants of different peripheral regions. This inter alia reflects a dependence on personal experience with travel abroad.

In turn, critical geopolitics has been criticized for an excessive focus on the analysis of texts, the misuse of constructivism at the expense of the study of the institutional and material basis of political discourse, insufficient attention to the material and historical basing of geopolitics as a whole, and eurocentrism (see, for instance, Ó'Tuathail 2010). This criticism resulted in a more frequent use of the critical approach, in combination with more traditional methods of geopolitics and political geography, especially the functional and structuralist ones. The 'good old' functional approach developed by generations of scholars keeps its heuristic role. In political geography, it is based on the classic works by Jean Gottmann (1952) and his notion of communication, and by John House (1982), who proposed a theory to account for interactions between neighbouring countries. 


\section{Data and methodology}

The paper is based on the findings of the EuroBroadMap international project (http://www. eurobroadmap.eu), as funded by the 7th European Framework Programme and coordinated by Prof. Claude Grasland (France). The main objective of the project was to analyse the way in which people's visions of Europe and the world are shaped - firstly, by their historical, political and economic backgrounds; gender; number of languages spoken and personal experience; and secondly, in relation to the real importance of each country in the world economy and politics, and its place in the space of flows. This was all evaluated by means of an analysis of the geographical distribution of foreign trade and foreign direct investments, the pattern of migrations, regular air flights and voting at the UN General Assembly at present, in the mid-1980s and in earlier periods. The initial hypothesis supposed that the geopolitical vision of the world depended on physical and cultural distance between countries (or similarity as regards language and religion).

This task required a combination of the methods developed within the framework of the critical and functional approaches to geopolitics. This entailed methods typical for critical geopolitics like surveys, discourse and text analysis, and mental mapping, alongside a diachronic analysis of world flows and patterns.

The project was in particular based around a survey of about 9,400 undergraduate students from 18 countries that was conducted in late 2009. The list of the latter included both EU Member States 'old' (France, Belgium, Sweden, Portugal) and 'new' (Romania, Hungary, Malta), as well as an EU candidate country (Turkey), some countries of North and Tropical Africa (Egypt, Cameroon and Senegal) and, finally, the countries of the BRIC group (i.e. Brazil, Russia, India and China). In order to make the results more compatible in all countries, the sample embraced students of the third year studying six groups of disciplines: medicine, engineering and informatics, music and arts, political science and other human sciences including geography. The opinions of the students were compared with the official political discourse and the image of the outside world presented in school textbooks on geography, as a relevant source of social representation.
The objectives of this paper were two-fold: firstly, to compare the world vision and the attitude to Europe among young people in BRIC and other countries; and, secondly, to analyze the place of popular representations in the dynamic of their identities, and the relations of the world geopolitical vision with the real importance of BRIC states in the space of flows.

A large area of territory, a significant population and GDP all exert a strong impact on a country's economy and politics. a large space makes more complicated the relations between the core, and a periphery whose external linkages compete with the internal ones. Obviously, large countries like those of the BRIC group are very diverse culturally; they often have a federal structure and numerous territorially compact minorities. This generates problems with national identity and cohesion. Large countries have specific geopolitical ambitions. a number of them were vast empires in the recent past, and they have difficult relations with their neighbours. All in all, the impact of the large extent of territory, population and GDP on society is assuming the status of special theme in geographical studies (see, for instance, Treivish 2009).

In answering the question "Where, in which country and locality do I live?", the individual unavoidably answers the question "Who am I?", "What are my ideals and values?". Naturally, these answers change with time. The geopolitical situation of a country changes under the impact of various global and other external processes, but also because people revisit their attitudes to different levels of power. The world geopolitical vision has aspects that are: a) historical (attitudes to events of the past), b) representative (ideas, principles, values and models which the state believes fundamental) and c) relational (attitudes to other actors and communities). a comparison of the situation in the country with which an individual associates himself and other countries is then made, particularly in regard to neighbours: here and there, good and bad. The EuroBroadMap project has mainly focused on these relational aspects.

Two key questions of the EuroBroadMap survey concerned countries in which respondents would or would not like to live. The total number of mentions of a country revealed the level of knowledge of it, and the balance between the number of positive and negative mentions divided by the total number of mentions is then called the ratio of 
asymmetry - a variable that helps with comparisons of respondents' attitudes to each country.

Globalization has been contributing to a homogenization of the world geopolitical vision, and of the models of human self-identification with different territories. The global market for information endows countries with a standard set of markers, differentiating and sorting territories. These markers shaping geographical images are used as an efficient tool by which the interests of major powers can be promoted, this being part of cultural imperialism and hegemony as an element of the geopolitical world order (Taylor 1994). At the same time, the standardization of the world geopolitical vision is a part of the general crisis of identity observed in many countries.

\section{The world viewed from large countries: common and specific features}

\section{'Europhilia' and the reasons for it}

General features of the world geopolitical vision referred to by students from the BRIC countries are the same as in other countries included in the survey. More or less distinct representations of the outside world concern no more than 35-40 countries regularly covered by TV and other media. The list of these countries mainly includes the large and rich countries that are the most important 'newsmakers'.

In all countries, the respondents expressed their admiration of Europe, and particularly of the largest countries of Western Europe, i.e. France, Great Britain (the UK), Italy and Germany. These countries are widely known and have a highly positive ratio of asymmetry (see, for instance, Fig. 1). Within the group of BRIC countries, Russia boasts the students with the most Europe-oriented image of the world. They are also the most Francophile of any in the whole sample of 18 countries.

Some reasons for this 'Europhilia' are common to all four countries in the group. Obviously, Europe is attractive thanks to its high level of wellbeing, associations with tourism and leisure, its historical and cultural heritage and its democratic systems of governance. In line with their importance in the world economy and politics, European countries, especially the largest, are covered extensively by the mass media, as well as in school textbooks.
Equally, it is natural enough that many of the reasons for 'Europhilia' are seen to differ among four countries situated in opposite parts of the globe. In Brazil and India, the interest is partly explained by the colonial past, and hence the deep relationships pertaining with Portugal and the United Kingdom, respectively. In India, the British influence is quite visible in many spheres like the legal system and education, architecture, the mass media, codes of conduct and cultural heritage. a powerful geopolitical factor behind political alliances and perceptions is language. Brazil and Portugal share the same tongue, and in India English is one of the official languages, while in China it is the most commonly spoken foreign language. Chinese students cite more often - and more positively - the UK and the countries of north-western Europe, where English is widely-used, than France or Italy. For Brazil and India, Western Europe is also a potential destination for labour migrations. The large Indian diaspora in the UK and other West European countries also shapes the sympathies of Indian students.

In Russia, the numerous sociological studies conducted by all the major agencies show a considerable degree of stability to Russian citizens' sympathy with Europe (Kolosov 2003). For instance, in 2006, a national survey revealed that $83 \%$ of respondents had positive associations with the continent. Despite the diet of antiWestern propaganda the federal TV channels offered in the 2000s, every third respondent in national surveys would like the Russian Federation to become a full EU Member State. Russian citizens see European countries as potential political allies more than twice as often as they do the US. The EuroBroadMap survey confirmed the conclusion of previous studies that the vision of Europe in Russia has two strata: a more superficial economic one, and a deeper cultural-historical one. The economic explanation is the same as in many other countries: Russian citizens want to live like Europeans and to have the same rights as they do. Membership of the EU as a club of prosperous countries is considered a question of prestige. Visa-free movement across the countries of the EU is also of very important symbolic significance to Russian citizens. It is not by chance that this is one of the priorities where relations between Russia and the EU are concerned. Europe is also associated with more democratic freedoms and international security. 


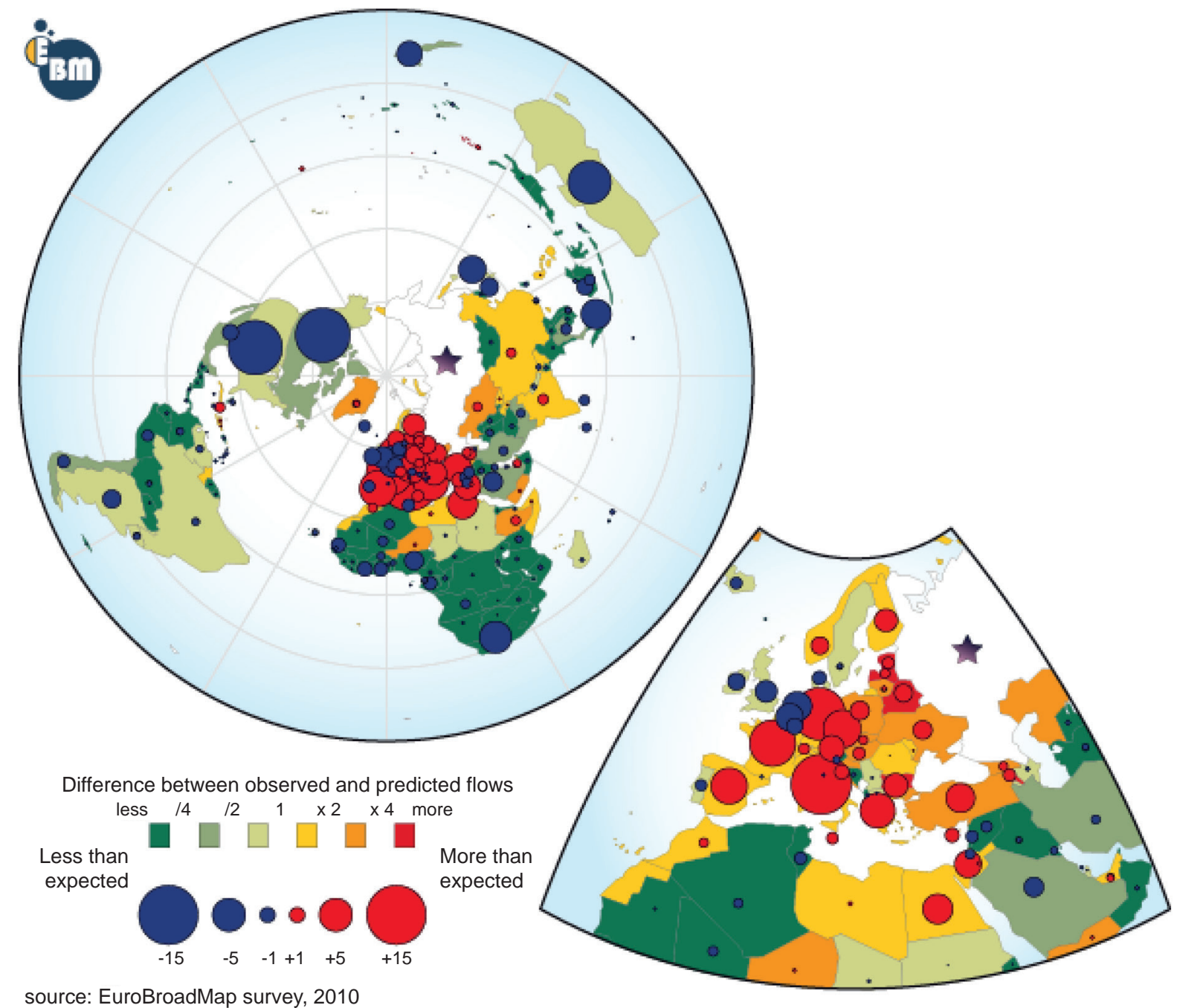


Students in Brazil, Russia, India and China share an attitude towards the US that may be viewed as controversial. The number of those who would like, or would not like, to live in the US is more balanced, while in the EU the image of this country is clearly positive. Their citizens are against a unilateral American political, military and cultural hegemony. BRIC countries as large powers pretend to an autonomous role in world politics, these claims being at least partly based on high rates of economic growth in the 2000s. China is now the world's number 2 economic power, often referred to as the superpower of the 21st century. In China, India and Russia, national identity is based on pride in a secular historical past, and cultural traditions opposed to American mass culture. Within the BRIC group, the most positive attitude to the US is that displayed in India, perhaps because of a more pragmatic foreign policy of this country, which sees the US influence as a counterbalance to China's geopolitical ambitions.

With a few exceptions, the citizens of the BRIC countries do not find neighbouring countries particularly appealing. Indians would not like to live in Pakistan, Bangladesh or Nepal, while for Russians no parts of the former Soviet Union are attractive, and neither is almost any part of Asia to Chinese students. Among the Brazilians' neighbours, only Argentina and Paraguay are the subject of a balanced appraisal. Neighbouring countries are usually relatively well-known to public opinion, and are not thus as exotic as some more remote destinations. More importantly, perhaps, the neighbouring countries are usually poorer than the large regional powers.

\section{The impact of distance}

The factor of distance, or cultural proximity, sometimes has an impact on students' perceptions. The role of India as a regional power is visible in respondents' sympathies for Malaysia, Australia and Singapore. But again, the last two countries belong to the 'First World'. Singapore with its high standards of living and skyscrapers is represented as the 'Oriental West' close to India.

Local factors are better seen when BRIC countries are compared with the sample as a whole. Such comparisons discover, for instance, that the countries of Latin America are more attractive to Brazilians and South East Asia to Indians, while Indian and Chinese Europhilia is relatively weaker than in absolute terms. However, this does not modify the overall conclusion that cultural proximity plays a less important role in students' preferences than wellbeing and economic prosperity.

As among the respondents from all other countries, Middle Eastern states like Iran, Iraq and Afghanistan are perceived most negatively by the students from the BRIC countries: almost nobody wants to live there. Because of the largescale international conflicts regularly covered by the mass media and mentioned in the political discourse of national leaders, these countries are widely known. But they are seen as strongholds of Muslim fundamentalism and intolerance, as the foci of irreconcilable conflicts and civil wars, and as sources of political instability.

The attitude of the BRIC students to other countries within this group is an interesting question. Indians, Chinese people and - to a much lesser extent - Brazilians reveal a better view on Russia than do participants in the sample as a whole. In India, this country has long been perceived as an ally and a friendly offerer of support during international conflicts in the past. In turn, in China, Russia is perceived as a good and relatively wellknown neighbour.

At the same time, China does not evoke particularly warm feelings in Brazil - perhaps because of the cultural distance and because Chinese society is perceived as too rigid. In India and Russia, the attitude to China is more balanced, but this country still does not look attractive. Russian students still consider India to be a part of the poor and non-attractive global 'South', while Brazil is an interesting destination for them.

The world geopolitical vision and territorial selfidentification of the students from BRIC countries are, to a significant extent, explained by limited international mobility reflecting both low per-capita income and the sheer size of these countries. The geopolitical imagination of the respondents is visibly inspired by stereotypes from the media, and is sometimes bookish. For example, in India, Europe is associated with Switzerland and France, because these countries represent it in innumerable movies in Hindi, particularly those filmed by popular Bollywood director Yash Chopra. BRIC students travel mostly to neighbouring countries, to a limited number of nearby popular tourist destinations (Singapore in the case of India, Turkey and Egypt for Russia), as well as to some developed countries (the USA and Japan in the case of 
China, the USA and UK in the case of India, Western Europe as a whole in the case of Russia).

Not surprisingly, the citizens of large countries (India, China and Russia in particular) identify themselves predominantly with their states. Russian students demonstrated the highest level of national self-identification in any of the 18 countries studied.

Indeed, the global identity of 'citizens of the world' is mainly a feature of Western countries. Though it is being diffused in non-Western countries, its values associated with the American and Western influence often provoke growing rejection. For instance, in Muslim countries only $4 \%$ of citizens believe that global problems are really relevant. According to a recent (2009) survey conducted in 45 countries concentrating more than two-thirds of world population, $66 \%$ of respondents associate themselves first and foremost with their countries, and $10 \%$ with 'citizen of the world' status, while $20 \%$ combine national identity with faith in common human values (Zagladin 2011).

A strong national identity as revealed by the survey is particularly important for such ethnically and culturally diverse countries as India; obviously, young people consider its integrity an important value. This is also true of Russia, though the survey there was only conducted in predominantly Russian cities.

\section{World regions, the boundaries of Europe and self-identification of respondents}

The questionnaire of the EuroBroadMap survey included three original questions: the respondents were asked to draw on the map the boundaries of Europe, and of the region with which they associate themselves, and to delimit three to ten regions of the world. These drawings can be summarized by special software and analyzed by national, social and regional group. The results of this analysis bring new elements to light where the relations in the classical territory-boundaries-identity triad are concerned.

The conventional boundary between Europe and Asia along the Urals was drawn relatively rarely, and its location was not very often correct. The refusal of many students in BRIC and other countries to recognize it contradicts with the rules commonly adopted in the delimitation of Europe. In school textbooks, Europe is almost everywhere portrayed as a continent of clearly and strictly delimited boundaries along the Mediterranean shore to the south and the Urals to the east. European scholars now believe that the boundary between Europe and Asia is a fully social construct invented for political purposes in the 18th century (see, for instance, Lévy 1995 and Foucher 2000). Still, Russian geographers try to prove that the Urals constitute both a natural physical barrier and a socio-cultural boundary, using data on climate and soils, vegetation and ethnic divides (Chibilev 2011).

It is thus a frequent enough occurrence for the boundary between Russia and its western Slavonic neighbours - Ukraine and Belarus - to be presented as the boundary of Europe. In other words, a significant share of the students represent Russia as a separate world, and this is indeed true of a significant proportion of Russian students themselves. Nevertheless, many Brazilians and Chinese (and a smaller proportion of Indians and Russians) have a tendency to include all of Russia in Europe.

As for Turkey, Chinese and Brazilian students are more prone to consider it a European country. This opinion is shared by only a small minority of Indians and Russians. Overall, Turkey looks isolated on the mental map of Europe.

Citizens of large countries are prone to associate the world region in which they live with their country or the confines of former empires. Chinese students most often call their world region either 'Asia' or 'China'. So do Indians, though unlike the Chinese they prefer the term 'India' to 'Asia'. Brazilians usually call their region of the world 'South America' and only rarely simply 'Brazil'. At the same time, some of the common abstract notions developed in 'high' geopolitics like 'Latin America', the 'Third World' or 'Slavic countries' are not popular, and remain therefore the mental constructs of the elite.

The answers of Russian students to these questions are particularly interesting. The eternal questions of 'high' and 'low' Russian geopolitics are:

a) is Russia a European country? and

b) is it a unique Eurasian country which should look for its own developmental path? Specifically, should it carefully protect its sovereignty as an independent center of the multi-polar world?

c) is it the leader of a specific Eurasian civilization - in other words, should it seek to reintegrate the post-Soviet space and at what price? A semantic and cartographic analysis confirms the main 
role of national identity and of self-identification of students with Russia as a separated world. This means that most respondents reject the associations with the former empire, the Soviet Union, just 20 years after its disintegration. However, characteristically, 'Europe' is the second most important name given by respondents to their region. The word 'Eurasia', whose cultural and historical connotations are quite different in Russia, is only mentioned far more rarely.

In all countries, Europe is to a large extent monopolized by Western Europe and the EU. However, if the outer boundary in the south (separating Europe from Africa) is clear, as in the west and north, it is less obvious in the east and the south-east. The most European territories in the mind of students encompass the current Member States of the EU, and primarily its historical core i.e. the countries which founded it in the 1950s, mostly France and Germany. For instance, in the eyes of Indian respondents, these two countries are the most European. Students imagine 'Europeanness' declining gradually from this core in the direction of the periphery, particularly eastward. Even Northern Europe (Scandinavia and Finland) are viewed as 'less European' than the foundercountries of the EU. Unlike the respondents from Brazil, Russia and China, many Indian students consider the UK apart from continental Europe - probably because this country has not entered the Schengen area and has not accepted the euro.

A highly positive perception of European countries is confirmed by an analysis of the words associated with Europe. The R-analysis demonstrated that the lower the estimated family incomes, the less emotional and more complicated the views of students. Likewise, the more foreign languages a student speaks, the more profound his/her representations. Female students usually share a more glamorous image than men. Young people from more central cities imagine Europe in a more adequate way. Brazilians, Chinese and Indians primarily associate the word 'Europe' with such economic terms as 'development', 'wealth', 'advanced', 'rich', etc., though some take a more romantic view (e.g. 'beauty', 'elegant', etc.), with associations relating to cultural and historical heritage and a high level of education, democracy and freedom. Russians have developed a more institutional vision of Europe (relating to the 'EU', the 'euro' and even 'NATO'). So, the notion of Europe in the minds of these people is closely con- nected with the European Union as a club of prosperous and democratic states, and its currency. In the rest, the associations are similar to those among respondents of other countries.

From the functional perspective, the world vision of students from the BRIC countries mostly matches the geographical pattern depicting the flows that connect their countries with the outside world. In general, the main trend to the dynamics of foreign trade was considerable growth in turnover with the EU-15. Brazil, Russia and India look like typical countries on the world's semi-periphery. In terms of the technological structure of their foreign trade, they are dominated by advanced economies providing them with more complicated goods while, they in their turn dominate their immediate periphery. Despite the reorientation of their foreign trade in absolute terms, the BRIC countries usually maintain preferential trade relations with their neighbours. It is important to notice that growing trade with China is not yet mirrored in perceptions of it: the share of those who would not like to live there still exceeds the proportion of those who are ready to move to this giant country.

In contrast, it looks as if the pattern to voting at the UN General Assembly in 2009-2010 was to a great extent inherited from the era of the bipolar world, despite the major changes on the world political and economic map that have taken place. The major cleavages are East-West and North-South. Though there are some nuances, the pattern in general is rather simple: BRIC countries select the same options as most countries of the world 'South' (Latin America, Africa and Asia), or, vice versa, the world 'South' votes in the same way as BRIC.

\section{Conclusion}

The results of the EurioBroadMap project emphasize the role of well-being as the main factor shaping the world geopolitical vision in different countries and, in particular, in the BRIC group embracing about $40 \%$ of the world population. The survey conducted within the framework of the project showed the conflation of the notions of 'Europe' and of the EU, which has important political consequences contributing to the isolation of the EU from its neighbours, and giving rise to a sequence of exclusions and self-exclusions in the countries situated close to its borders. Despite progressing globalization, the national level of 
self-identification still clearly dominates - at least in large countries. As the example of China demonstrates, the dynamics of the countries' image has a strong inertia. and does not necessarily follow change in the situation in the space of flows and the place in the world. From the functional perspective, China, Brazil and Russia belong to the global semi-periphery, and in terms of the technological structure of their foreign trade they

\section{References}

ArCher J.C., Shelley F.M., Leib J.L., 1997. The perceived geopolitical importance of the countries of the world: An analytical and pedagogical investigation. Journal of Geography, vol. 96, no. 2, pp. 76-83.

Brewer P.R., Gross K., Aday S., Wilnat L. 2004. International trust and public opinion about world affairs. American Journal of Political Science, vol. 48, no. 1, pp. 93-109.

Chibilev A.A., 2011. Evro-Aziatskaia granitsa: istoria voprosa i sovremennye prestavlenia. All-Russian NonGovernmental Organization. Russian Geographical Society, Internet: http://www.rgo.ru/2011/02/evroaziatskaya-granica-istoriya-voprosa-i-sovremennyepredstavleniya/ [1 October 2012].

DalBy S., Ó’TUathall G., 1998. Rethinking geopolitics. London: Routledge, 333 pp.

DIJKINK G.-J., 1998. Geopolitical codes and popular representations. GeoJournal, vol. 46, no. 4, pp. 293-299.

Dodds K., 2008. Counter-factual geopolitics: President Al Gore, September 11 and the Global War on Terror. Geopolitics, vol. 13, no. 1, pp. 73-99.

Foucher M., 2000. La République européenne. Paris: Belin, $147 \mathrm{pp}$.

GotTMAnN J., 1952. La politique des états et leur géographie. Paris: Armand Colin, 228 pp.

HARVEY D., 1990. The condition of postmodernity. Oxford: Blackwell, 378 pp.

HOUSE J.W., 1982. Frontier on the Rio Grande: a political geography of development and social deprivation. Oxford: Clarendon Press, 281 pp.

Kolossov V. (ed.), 2001. Collocazione Geopolitica della Russia: Rappresentazioni e Realtà. Torino: Edizioni della Fondazione Giovanni Agnelli, 355 pp.

Kolossov V. (ed.), 2003a. Mir glazami rossian: obshchestvennoye mnenie i vneshnia politika. Moscow: Institut Fonda "Obshchestvennoe mnenie", 286 pp. are at the same time dominated and dominating. This situation is reflected in the world vision of students and, in particular, in the perceived attractiveness of Europe.

Editors' note:

Unless otherwise stated, the sources of tables and figures are the author(s), on the basis of their own research.

Kolossov V., 2003b. 'High' and 'low' geopolitics: Images of foreign countries in the eyes of Russian citizens. Geopolitics, vol. 8, no. 1, pp. 121-148.

Le Monde Diplomatique, 2009. L'Atlas du Monde diplomatique. Paris: Armand Colin, 232 pp.

LÉVY P., 1995. Qu'est-ce que le virtuel? Paris: La Découverte, $156 \mathrm{pp}$.

Mamadoun V., DiJkink G., 2006. Geopolitics, international relations and political geography. The politics of geopolitical discourse. Geopolitics, vol. 11, no. 3, pp. 349-366.

O'LoughuIN J., 2001. Geopolitical fantasies, national strategies and ordinary Russians in the post-communist era. Geopolitics, vol. 6, no. 3, pp. 17-48.

O'Loughuin J., Kolossov V., 2002. Still not worth the bones of a single Pomeranian grenadier: The geopolitics of the Kosovo war 1999. Political Geography, vol. 21, no. 5, pp. 573-599.

O'Loughlin J., Ó'Tuathail G., Kolossov V., 2005. Russian geopolitical culture in the post 9/11 era: The masks of Proteus revisited. Transactions of the Institute of British Geographers, vol. 30, iss. 3, pp. 322-335.

O'Loughlin J., TAlBOt P., 2005. Where in the world is Russia? Geopolitical perceptions and preferences of ordinary Russians. Eurasian Geography and Economics, vol. 46, no. 1, pp. 23-50.

Ó'Tuathall G., 2003. Geopolitical structures and geopolitical cultures: Towards conceptual clarity in the critical study of geopolitics. [in:] L. Tchantouridze (ed.), Geopolitics: global problems and regional concerns, Bison Paper, 4, Winnipeg: Centre for Defence and Security Studies. University of Manitoba, 248 pp.

Ó'TuAtHAIL G., 2006. Thinking critically about geopolitics. [in:] G. Ó’Tuathail, S. Dalby, P. Routledge (eds.), The geopolitics reader, 2nd edn., London-New York: Routledge, 302 pp. 
Ó’TUATHAIL G., 2010. Localizing geopolitics: Disaggregating violence and return in conflict regions. Political Geography, vol. 29, no. 5, pp. 256-265.

SACK R., 1986. Human territoriality: Its theory and history. Cambridge Studies in Historical Geography, 7, Cambridge-New York: Cambridge University Press, $256 \mathrm{pp}$.

Sharp J., 2000. Condensing the Cold War: Reader's Digest and American identity. Minneapolis: University of Minnesota Press, 207 pp.

TAYLOR P.J., 1994. The state as container: Territoriality in the modern world-system. Progress in Human Geography, vol. 18, no. 2, pp. 151-162.
TReIVISH A.I., 2009. Gorod, raion, strana i mir: Razvitie Rossii glazami stranoveda. Moscow: Novyi Khronograph, 369 pp.

ZaGLADIN N.V., 2011. Konflikt identichnosti v epokhu globalizatsii. [in:] I. Semenenko, L. Fadeeva (eds.), Identichnost' kak predmet politicheskovo analiza, Moscow: Institute of World Economy and International Relations of Russian Academy of Sciences, pp. 74-78. 